\title{
Assessment of Technology Transfer from Grid power to Photovoltaic: An Experimental Case Study for Pakistan
}

\author{
Umer Farooq $^{1}$, Habib Ullah Manzoor ${ }^{2}$, Aamir \\ Mehmood $^{3}$, Awais Iqbal $^{4}$, Rida Younis $^{5}$, Amina Iqbal $^{6}$ \\ Faculty of Electrical \& Mechanical Engineering, University \\ of Engineering and Technology \\ Lahore (FSD-Campus)-38000 \\ Pakistan
}

\author{
Fan Yang ${ }^{7}$, Muhammad Arshad Shehzad Hassan ${ }^{8}$, \\ Nouman Faiz ${ }^{9}$ \\ State Key Laboratory of Power Transmission Equipment, \\ and System Security and New Technology \\ School of Electrical Engineering, Chongqing University \\ Chongqing 400044, China
}

\begin{abstract}
Pakistan is located on the world map where enough solar irradiance value strikes the ground that can be harnessed to vanish the existing blackout problems of the country. Government is focusing towards renewable integration, especially solar photovoltaic (PV) technology. This work is focused to assess the techno-economic viability of different PV technologies with aim of recommending the most optimum type for domestic sector in high solar irradiance region of the country. For this purpose, standalone PV systems are installed using monocrystalline (m-Si), polycrystalline (p-Si), and amorphous crystalline (a-Si) modules on the rooftop at $31.4{ }^{\circ} \mathrm{N}$ latitude position. The performance of $\mathrm{PV}$ modules is evaluated based on, average output power, normalized power output efficiency, module conversion efficiency, and performance ratio. Results elaborated that $\mathrm{m}$-Si module is the optimum type for the application with $23.01 \%$ average normalized power output efficiency. Economics of the system has also been evaluated in terms of the price of power value produced by PV modules with respect to the consumption of that power value from grid source in base case. Integration of such type of domestic PV systems are a need of time to make the future sustainable.
\end{abstract}

Keywords-Solar energy; photovoltaic technologies; module efficiency; power demand satisfaction; economics

\section{INTRODUCTION}

Energy is the main driving force behind the dynamics of the world. The whole world is running after energy sources to make the future brighter and sustainable. Since the evolution of modern civilization on earth, electricity production is largely dependent on fossil fuels. With scientific technology advancement in 21 st century, innovative techniques and inexhaustible energy sources are making their way to meet new standards. In this context, renewable energy sources (RESs) are the focus as they are everlasting and are not associated with threat of being extinct, as fossil fuels are. Significant amount of energy security, climate change mitigation, and certain economic benefits can be achieved by the speedy deployment of RESs [1-3].

Among renewables, solar (photovoltaic) PV technology is one of the most auspicious and emerging one in the whole world. Pakistan is considered at naturally blessed location on world map for solar applications due to its geographical location, climatic situation, and high solar insulation value [4]. Even Pakistan is facing severe energy crisis presently despite of the reported potential of $455.3 \mathrm{GWh}$ electric power generation through harnessing solar irradiance energy using off-grid type PV systems only [5].

Solar energy harnessing through PV system is dependent on the type and performance of PV module. The performance of PV modules varies depending on the geography and climatic conditions of the location [6]. In PV technology, electricity can be generated directly from solar energy but with low conversion efficiency, and needs much improvement in conversion technology [7]. It requires a lot of efforts to achieve maximum energy from the PV panels. The basic need to test PV modules at outdoor real time conditions is to estimate the output power of PV modules under variant environmental conditions [8-9]. Parameters of PV modules estimated on the standard testing conditions (irradiance $1000 \mathrm{~W} / \mathrm{m}^{2}$, module temperature $25^{\circ} \mathrm{C}$, and $\mathrm{AM} 1.5$ ) are not equal to the real time operating conditions due to the variations in environmental parameters [10].

Amin et al., [11] conducted an experimental study for the evaluation of the performance of four PV modules (m-Si (monocrystalline), p-Si (polycrystalline), a-Si (amorphous crystalline), and copper indium diselenide (CIS)) in Malaysia for three consecutive days. Results showed that CIS module has higher performance ratio (PR) value while $\mathrm{m}$-Si module has high module efficiency among all the modules tested. Midtgard et al., [12] conducted the experimentation for the performance evaluation of three different types of solar panels (m-Si, p-Si, and a-Si) in the climate of Norway. It was found that $\mathrm{m}$-Si was better in terms of average output power and module efficiency compared to $\mathrm{p}-\mathrm{Si}$ and a-Si modules.

The efficiency of PV modules depends on various environment associated factors such as dust accumulation, wind speed, wind direction, temperature, humidity etc., [1314]. Catelani et al., investigated the effect of dust and pollution on PV module performance using statistical approach [15]. From the statistical hypothesis test, the maximum power values showed decrement with the dust accumulation on panel 
surface. Mekhilef et al., investigated the effect of dust, humidity, and air velocity simultaneously [16]. They concluded that effect of each parameter should not be studied separately during estimating the cell efficiency by ignoring the other factors. P. Ferrada et al., investigated the performance of PV modules in the coastal zone of Antofagasta, Northern Chile for about 16 months [17]. They concluded that PR value of PV modules decreases due to dust accumulation. They also analyzed that difference of energy yield between the different technologies became higher for summer and lower for winter season. Generally, performance of PV modules decreases when temperatures of surroundings increases above the nominal operating temperature range [18]. Due to increase in air temperature, PV modules undergo severe degradation, consequently they cannot achieve maximum performance, therefore immediate cooling must be provided [19-20].

The best approach is to manage the light collecting capability and optimizing the temperature of solar PV cell. Jiang et al., performed experiments on three solar cells in a laboratory with sun simulator and test chamber and concluded with decrease in output efficiency value of up to $26 \%$ when dust deposition density increased to $22 \mathrm{~g} / \mathrm{m}^{2}$ [21]. Bashir et al., reported the performance data for different PV modules (m-Si, $\mathrm{p}-\mathrm{Si}$, and a-Si) for the month of January in the climate of Taxila and found that $\mathrm{m}$-Si module was more efficient with demonstrated average module efficiency of $13.01 \%$ [22]. It was also found that a-Si module showed average PR 1.03 and performed better than other two modules at that site. Furthermore, module efficiency and PR showed decreasing trend with the increase in solar irradiance and module temperature after nominal operating temperature point.

The present experimental study was focused to assess the impact of technology transfer from grid source to renewables source i.e. PV. For this purpose, three types of PV technologies were tested. It was aimed to identify the optimum PV technology to recommend for domestic applications in middle planes of the country.

Three standalone systems using commercially available PV technologies (m-Si, p-Si, and a-Si) were installed at Faisalabad city (Latitude $31.4^{\circ} \mathrm{N}$, longitude $73.1{ }^{\circ} \mathrm{E}$ ) of Pakistan, a city with $3^{\text {rd }}$ largest population count. The experimental data was recorded in form of incident solar irradiance, output voltage, current, and module temperature values. Using these recorded values, techno-economic performance of different PV technologies was assessed based on output power, normalized power output efficiency (NPOE), module conversion efficiency, performance ratio, and economic impact in terms of domestic power demand satisfaction and consequent reduction in electricity bill.

The reminder of this paper is organized as follows: the methodology is presented in Section II. Section III briefly explains the results and discussions. The economic impact of power source replacement and conclusions are explained in Section IV and Section V.

\section{METHODOLOGY}

The standalone PV systems were installed using three commercially available different PV technologies to satisfy the curiosity that what will be the impact of transferring the power source from grid to PV renewable and which one PV technology can satisfy the domestic power demand optimally in the middle planes of Pakistan.

\section{A. PV System}

The standalone PV system is a type of off-grid system that generates direct current (DC) electric power. This harnessed solar power can be used directly through DC appliances, or indirectly in conventional AC (alternating current) systems after conversion.

The main component of a PV system configuration is its PV module. Considered types from available PV modules for current study are: $\mathrm{m}-\mathrm{Si}, \mathrm{p}-\mathrm{Si}$, and a-Si. The $\mathrm{m}-\mathrm{Si}$ modules are composed of silicon bars that are converted into wafers by cutting form single crystal of silicon for each cell. The m-Si panels are usually blackish in color. In p-Si solar panels, more than one crystal of silicon is heated to make wafers. Single cell of p-Si module consists of mixture of silicon crystals. These panels are generally blue in color. The a-Si modules fall into the category of non-crystalline thin film silicon solar cells. They typically hold less efficiency compared to $\mathrm{m}-\mathrm{Si}$ and $\mathrm{p}-\mathrm{Si}$ solar panels [23].

The specifications and characteristic parameters of all three types of PV modules, along with rated and measured values are tabulated in Table I. Rated values are those provided by manufacturer, while measured values are recorded at outdoor environment in real time conditions.

\section{B. Experimental Procedure and Setup}

Three standalone PV systems were installed at the rooftop of Electrical Engineering Department, University of Engineering and Technology (Faisalabad Campus). Each PV system was configured using a certain type of PV module from selected three technologies. The PV modules were tilted at latitude angle position of the location with the aim of working year around, as shown in Fig. 1.

The measurements were taken for thirty days in the months of Feb-March 2018 during sunshine hours starting from 7:00 a.m. to 6:00 p.m. on hourly basis. The PV modules were connected to digital multimeters to measure corresponding module output voltage and current values. For measuring global solar irradiance values incident on PV modules, light intensity meter with, $2000 \mathrm{~W} / \mathrm{m}^{2}$ measuring capacity, $0.1 \mathrm{~W} / \mathrm{m}^{2}$ resolution, 400 1000 $\mathrm{nm}$ spectral response, and $\pm 10 \mathrm{~W} / \mathrm{m}^{2}$ ) accuracy value, was used. The solar irradiance values were measured consecutively after every hour. The temperature of all the modules was recorded using infrared (IR) laser meter (with specifications: $\pm 2{ }^{\circ} \mathrm{C}$ accuracy, $-32 \sim 380{ }^{\circ} \mathrm{C}$ measuring range, $0.1{ }^{\circ} \mathrm{C}$ resolution). Digital multimeters were attached with each PV module, which was connected to electronic load to vary the output of the PV modules from zero to maximum. Complete schematic configuration of installed PV system with all measuring devices is portrayed in Fig. 2.

The characteristic parameters of PV modules based upon which PV module can be characterized and differentiated from each other are: maximum power, fill factor, normalized output efficiency, module efficiency, and performance ratio. These 
properties are calculated using base measured values (like V, I, E), and applying the following mathematical relations:

Maximum power: $\mathrm{P}_{\max }=\mathrm{V}_{\max } \times \mathrm{I}_{\max }$

Fill Factor: $\mathrm{FF}=\frac{\left(\mathrm{V}_{\max } \times \mathrm{I}_{\max }\right)}{\left(\mathrm{V}_{\mathrm{oc}} \times \mathrm{I}_{\mathrm{sc}}\right)}$

NPOE: $\eta_{\mathrm{p}}=\left(\frac{\mathrm{P}_{\text {meas }}}{\mathrm{P}_{\max (\mathrm{STC})}}\right) \times 100$

Module efficiency: $\eta_{\text {mod }}=\left(\frac{P_{\text {meas }}}{E \times A_{a}}\right) \times 100$

Performance ratio: $\mathrm{PR}=\frac{\left(\mathrm{P}_{\text {meas }} / \mathrm{P}_{\max (\mathrm{STC})}\right)}{(\mathrm{E} \times 1000)}$

Comparison cannot be done considering module output power values that are different for all the modules. So, to compare the performance of each module with other, measured output power is normalized to its output value calculated at standard temperature conditions (STC) by using Eq. (3). The module efficiency also depends on various other parameters like active area of the module which is actual area on which solar radiations strike. The PR is considered to check the performance of PV modules based on actual and theoretical energy outputs [24].

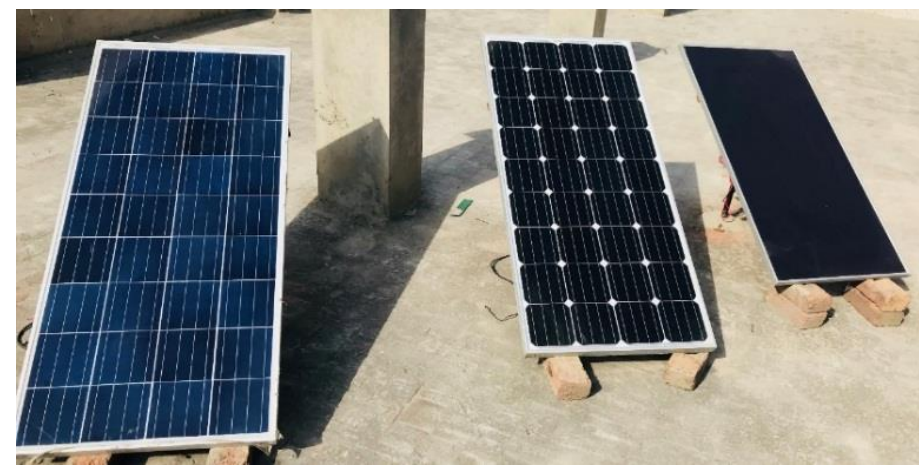

Fig. 1. PV Modules Installed at Experimentation Site.

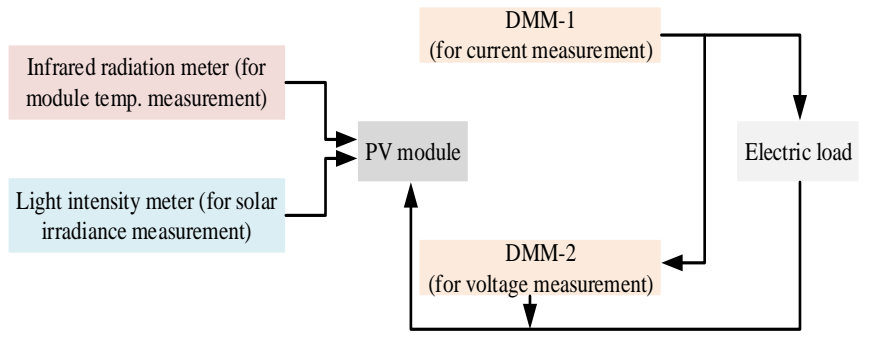

Fig. 2. Schematic Diagram of Experimental Setup.

TABLE I. PV MOdulEs SPECIFICATIONS, THEIR MEASUREd AND RATEd OUTPUT PARAMETRIC VALUES

\begin{tabular}{|c|c|c|c|}
\hline Parameter Name & $\mathbf{m}-\mathbf{S i}$ & p-Si & $\mathbf{a - S i}$ \\
\hline \multicolumn{4}{|l|}{ PV Module Dimensions } \\
\hline $\mathrm{PV}$ module dimensions $(\mathrm{mm} \times \mathrm{mm})$ & $1500 \times 700$ & $1500 \times 700$ & $1220 \times 620$ \\
\hline Cell dimensions $(\mathrm{mm} \times \mathrm{mm})$ & $155 \times 155$ & $155 \times 150$ & $1200 \times 600$ \\
\hline No. of cells in series & $4 \times 9$ & $4 \times 9$ & 1 \\
\hline Cell area $\left(\mathrm{m}^{2}\right)$ & 0.8649 & 0.837 & 0.72 \\
\hline \multicolumn{4}{|l|}{ Rated PV Module Specifications } \\
\hline $\mathrm{P}_{\max }(\mathrm{W})$ & 150 & 150 & 65 \\
\hline $\mathrm{I}_{\max }(\mathrm{A})$ & 8.75 & 7.9 & 0.94 \\
\hline $\mathrm{V}_{\max }(\mathrm{V})$ & 18.5 & 19 & 32.5 \\
\hline $\mathrm{I}_{\mathrm{sc}}(\mathrm{A})$ & 9.83 & 8.5 & 0.97 \\
\hline $\mathrm{V}_{\mathrm{oc}}(\mathrm{V})$ & 22.5 & 22 & 56.1 \\
\hline \multicolumn{4}{|c|}{ Measure Values of PV Module Outcomes } \\
\hline Avg. module temp. $\left({ }^{\circ} \mathrm{C}\right)$ & 36.70 & 37.47 & 37.18 \\
\hline Avg. module current (A) & 2.15 & 1.82 & 0.44 \\
\hline Avg. module voltage (V) & 14.52 & 14.08 & 9.83 \\
\hline Avg. module power (W) & 34.52 & 28.62 & 4.57 \\
\hline Avg. power output efficiency (\%) & 23.01 & 19.08 & 7.03 \\
\hline Avg. module efficiency (\%) & 8.29 & 6.30 & 1.16 \\
\hline Avg. performance ratio & 0.46 & 0.36 & 0.14 \\
\hline
\end{tabular}




\section{RESULTS AND DISCUSSIONS}

\section{A. Meteorological Parameters}

The PV off-grid type standalone system was designed and installed using three different PV technologies (m-Si, p-Si, a$\mathrm{Si}$ ). The performance of PV technology [25] is directly dependent on incident solar irradiance value. Incident solar irradiance intensity value is governed by meteorological parameters like ambient temperature, wind speed, and humidity mainly.

During the study, the daily average solar irradiance value recorded was above $500 \mathrm{~W} / \mathrm{m}^{2}$, with minimum $99.3 \mathrm{~W} / \mathrm{m}^{2}$ and maximum $683.3 \mathrm{~W} / \mathrm{m}^{2}$ values, as depicted in Fig. 3. These daily average irradiance values were in accordance with daily environmental temperature fluctuations except two days (rainy days). Because some hour measurements of these two days could not be recorded due to rainy weather. Fig. 4 shows the variations in hourly average solar irradiance for measurement days. The hourly average solar irradiance value increases linearly from morning hours with $101.07 \mathrm{~W} / \mathrm{m}^{2}$ to 1055.45 $\mathrm{W} / \mathrm{m}^{2}$ value at 12:00 p.m. hours, then decreases in the afternoon hours upto $18.49 \mathrm{~W} / \mathrm{m}^{2}$. The maximum hourly average incident solar irradiance value was recorded between 12:00-1:00 p.m. (as shown in Fig. 4).

Further the performance of three PV technologies is evaluated using following approaches to choose the optimum one:
- Module temperature analysis

- Average and normalized power output efficiency analysis and power delivered to load

- Module efficiency analysis

- Performance ratio analysis

\section{B. Module Temperature Analysis}

The PV module surface temperature depends upon incident solar irradiance intensity. The variations in hourly average module's temperature are shown in Fig. 5.

Analysis of Fig. 5 shows that increasing or decreasing module's temperature trend is in accordance with incident solar irradiance values (evident from the comparison of Fig. 5 bars against Fig. 4). The lowest hourly average module's surface temperature is recorded for $\mathrm{m}-\mathrm{Si}, \mathrm{p}-\mathrm{Si}$ and a-Si were equivalent to $15.12{ }^{\circ} \mathrm{C}, 15.09^{\circ} \mathrm{C}$, and $16.05^{\circ} \mathrm{C}$ at 7:00 a.m. in the morning respectively, and the maximum modules temperature values were $50.81{ }^{\circ} \mathrm{C}, 50.35{ }^{\circ} \mathrm{C}$, and $52.02{ }^{\circ} \mathrm{C}$ at 12.00 p.m. at noon respectively against highest hourly average incident solar irradiance values (as evident from Fig. 4). The Difference in surface temperature of different PV modules is very small, and that might be due to variations in glass type of glazing layer of module, as there was no shading effect on any of the module's surfaces.

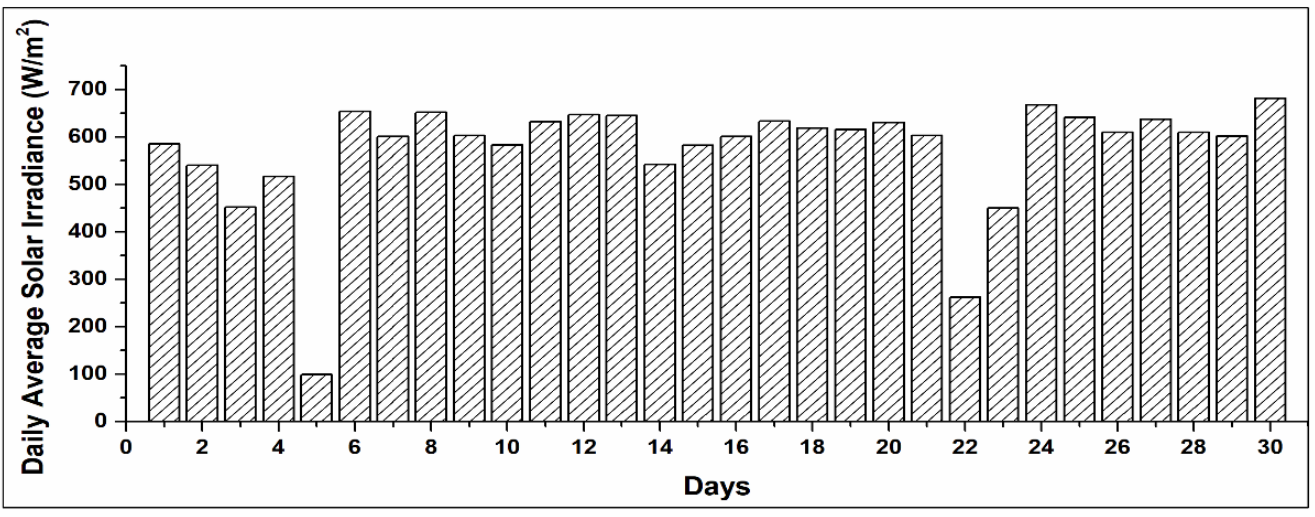

Fig. 3. Daily Avg. Solar Irradiance Values for Experimentation Days.

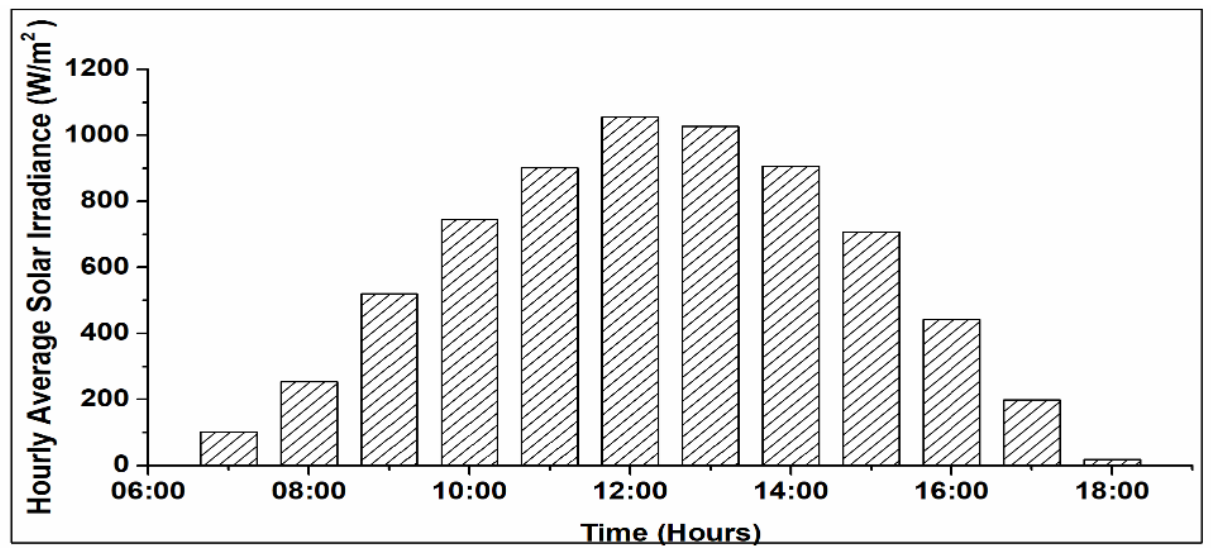

Fig. 4. Hourly Avg. Incident Solar Irradiance Against Time Hour for Experimentation Days. 


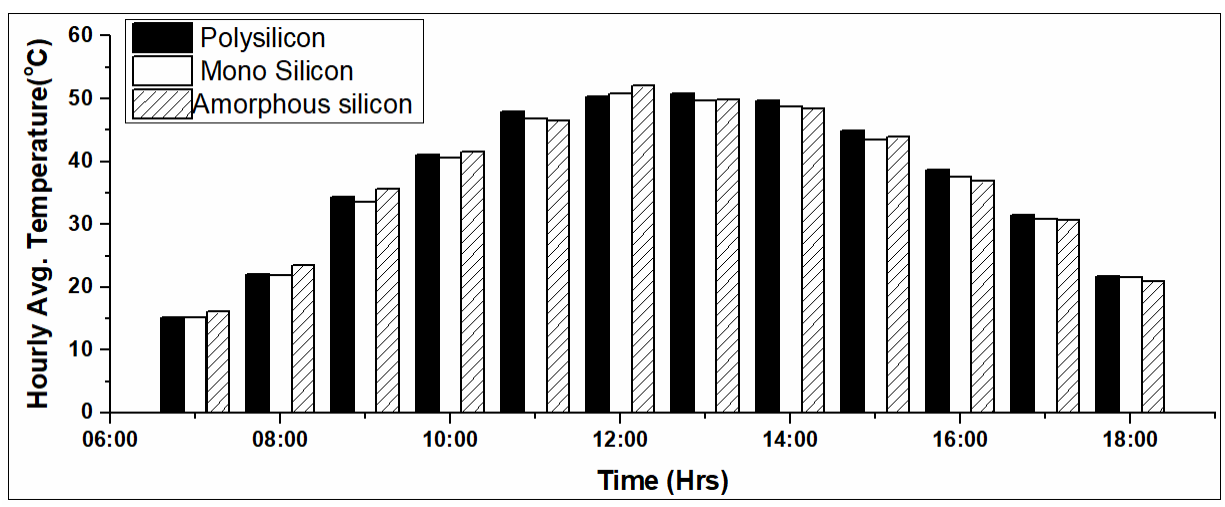

Fig. 5. Hourly Avg. Module Temperature Values.

\section{Normalized Power Output Efficiency (NPOE) and Power Delivered to Load}

Output power $\left(P_{\text {mea }}\right)$ is the main parameter to check the performance of any power generation source, to be installed. The average daily and hourly based output power $\left(P_{\text {mea }}\right)$ in watts of installed standalone PV generation sources is elaborated in Fig. 6 and Fig. 7, respectively. Output power in relation with maximum possible rated power from modules at STC is elaborated in Fig. 8 and Fig. 9 in form of normalized output power (Eq. (3)) against incident solar irradiance values and time, respectively.

Analysis of Fig. 6 shows that $\mathrm{m}$-Si type PV module produced daily output power in $27-49 \mathrm{~W}$ range, while p-Si and a-Si type PV modules generated $P_{\text {mea }}$ in $21-35 \mathrm{~W}$ and 3-7 W ranges respectively, ignoring the output of 2 rainy days. The $\mathrm{m}$-Si module generated the highest output power value of 48.8 $\mathrm{W}$ against $654.01 \mathrm{~W} / \mathrm{m}^{2}$ incident solar irradiance and $26{ }^{\circ} \mathrm{C}$ environmental temperature values while $\mathrm{p}-\mathrm{Si}$ produced maximum $P_{\text {mea }}$ of $34.1 \mathrm{~W}$ against $651.6 \mathrm{~W} / \mathrm{m}^{2}$ and $28{ }^{\circ} \mathrm{C}$ environmental temperature values. a-Si module generated in almost constant behavior with very small variations against measured range of incident solar irradiance values.

Analysis of Fig. 6 to 9 elaborates that increase in incident solar irradiance value corresponds to the increase in output power $\left(P_{\text {mea }}\right)$ and normalized output power values of all three types of PV modules, with maximum values generated by $\mathrm{m}-\mathrm{Si}$ type module followed by $\mathrm{p}-\mathrm{Si}$ and a-Si type PV modules in descending order. Daily individual analysis is also evident of the fact that output power value is in accordance with variations in solar irradiance value with maximum power generated values during 12:00-1:00 p.m. hour (evident from Fig. 7 and Fig. 9). Analysis of output power $\left(P_{\text {mea }}\right)$ and normalized output power curves conclude that $\mathrm{m}-\mathrm{Si} \mathrm{PV}$ technology is optimum type with $23.01 \%$ NPOE value, followed by p-Si and a-Si PV technologies with $19.08 \%$ and $7.03 \%$ NPOE values, respectively.

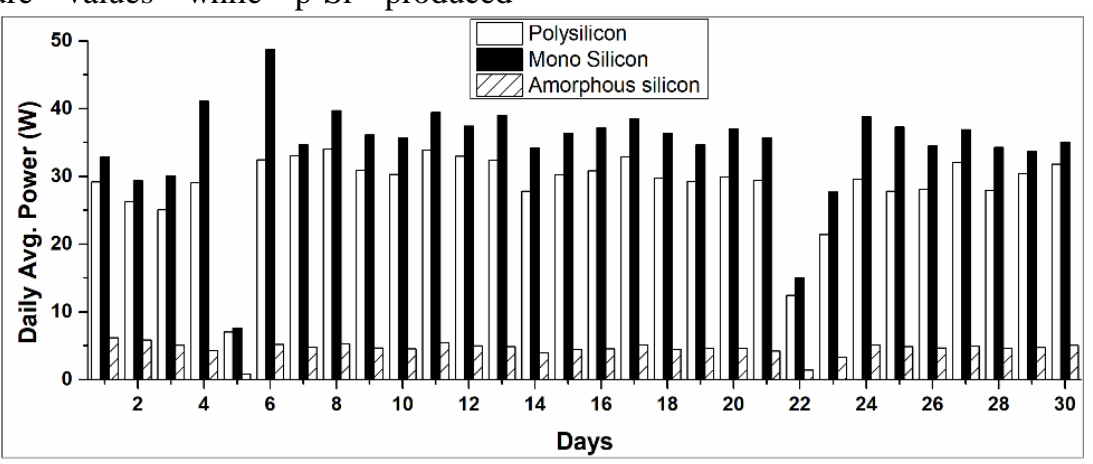

Fig. 6. Daily based Avg. Output Power of Experimentation Days.

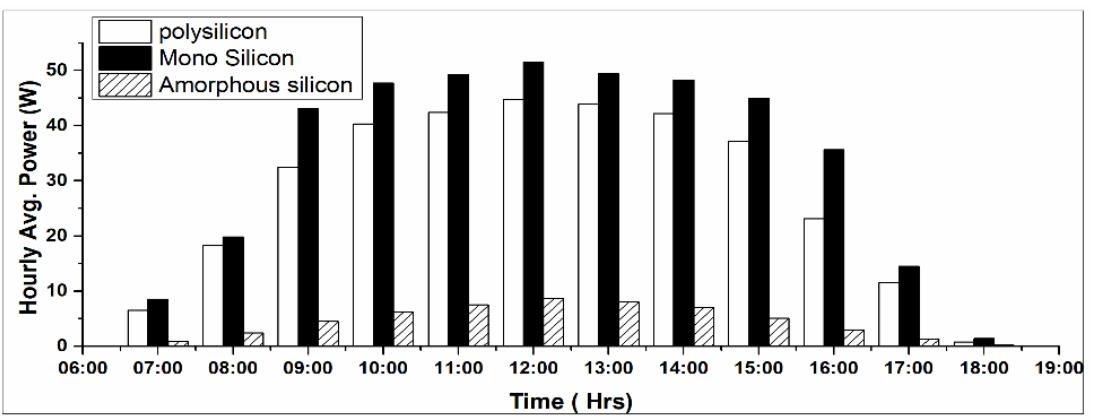

Fig. 7. Hourly based Avg. Power Output of Experimentation Days. 


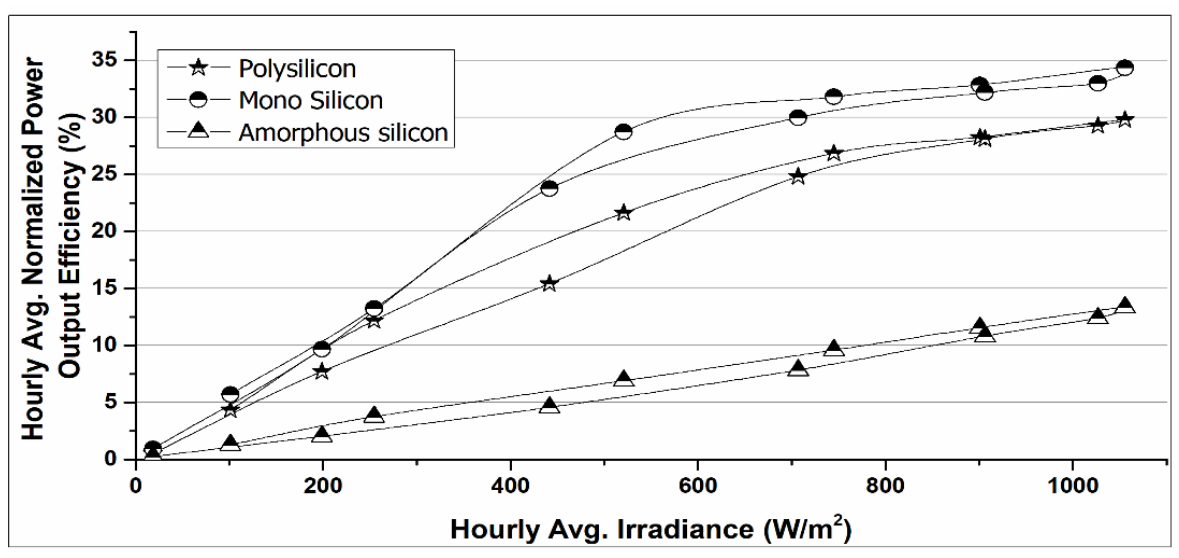

Fig. 8. Hourly based Avg. NPOE of PV Modules Against Avg. Incident Solar Irradiance Values.

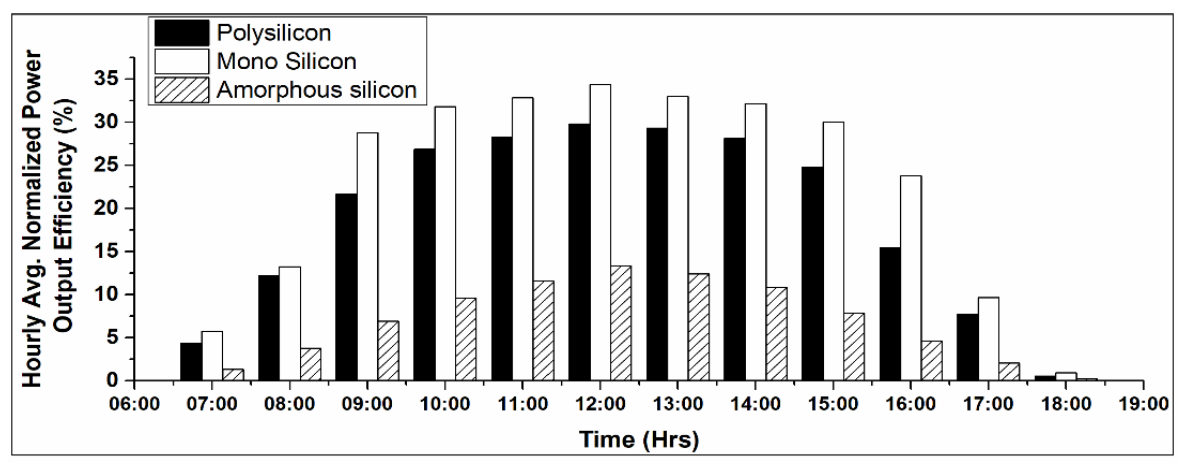

Fig. 9. Hourly based Avg. NPOE of PV Modules for Experimentation Days.

\section{Module Efficiency Analysis}

The PV module efficiency is an indicator of overall panel's quality, tells about the percentage of incident sun light spectrum being converted into useable electric power (Eq. (4)). The module efficiency is directly related to $P_{\text {mea }}$, while is in inverse relation with product of module surface area and solar irradiance value incident on it. Average module efficiency of three types of PV technologies against incident irradiance intensity values, and time of the days is described through Fig. 10 and Fig. 11, respectively.

Analysis of the Fig. 10 and Fig. 11 elaborates that module efficiency at real-time conditions could never be the same as reported by the manufacturers, because that value is reported under STC. Analysis of Fig. 10 and Fig. 11 supports the fact that module efficiency is in inverse relation with incident solar irradiance values, but after certain intensity value. There is a critical relation between incident solar irradiance value and surface area of the module. As every PV technology type works efficiently upto the certain module surface area and temperature in relation with incident solar irradiance value. The further increase in incident irradiance value against certain area value leads to decrease in overall module efficiency value, as is happening here. In the start of efficiency curves, module efficiency increases for $\mathrm{m}-\mathrm{Si}$ and $\mathrm{p}$-Si types against increasing irradiance value upto certain value at early day hours. Then further increase in irradiance value caused decrease in module efficiency for both types ( $\mathrm{m}-\mathrm{Si}$ and $\mathrm{p}-\mathrm{Si}$ ) of modules. Overall analysis of Fig. 10 and Fig. 11 elaborates that both $\mathrm{m}-\mathrm{Si}$ and pSi PV module types give high efficiency at early (i.e. morning) and late (i.e. afternoon) hours of the day with comparatively low incident solar irradiance values.

Comparative analysis of $\mathrm{m}-\mathrm{Si}$ and $\mathrm{p}-\mathrm{Si}$ modules shows that m-Si type PV technology gives higher efficiency values at lower incident solar irradiance values, while p-Si type modules gave higher efficiency value at relatively high incident solar irradiance values (as shown in Fig. 10). The a-Si type module shows almost constant behavior against the increase or decrease in incident solar irradiance values. Module efficiencybased analysis of three types of PV technologies to choose the optimum one among them concludes that m-Si type PV technology is the best option with $8.29 \%$ real time measured module efficiency, higher compared to that of $\mathrm{p}-\mathrm{Si}$ and a-Si type PV modules with $6.3 \%$ and $1.16 \%$ module efficiency values, respectively.

\section{E. PR Analysis}

The PR is description of real time quality factor of the PV plant/ module that tells about the relationship between actual and theoretically expected output of the PV plant (calculated using Eq. (5)). The PR value helps in estimating the final value of power would be available for exporting to grid after all loss's deduction. The hourly average (Avg.) PR against module temperature, and time is plotted in Fig. 12 and Fig. 13 respectively. Analysis of Fig. 12 and Fig. 13 elaborates that PV module types show the same trend in case of PR parameter as was for module efficiency (Fig. 10 and Fig. 11). The PR has decreasing trend in value against the increase in incident solar irradiance value. That's why $\mathrm{m}-\mathrm{Si}$ and $\mathrm{p}-\mathrm{Si}$ have relatively high 
PR values in early (morning) and late (afternoon) hours of the day with low incident solar irradiance values, compared to the hours (noon time) with high incident solar irradiance values. Comparative analysis of three PV module types concludes that
m-Si type PV modules is the optimum choice with $46.38 \%$ PR value (0.46), higher than that of $\mathrm{p}-\mathrm{Si}$ and a-Si type PV modules generating power with $36.43 \%(0.36)$ and $13.82 \%(0.14)$ PR values.

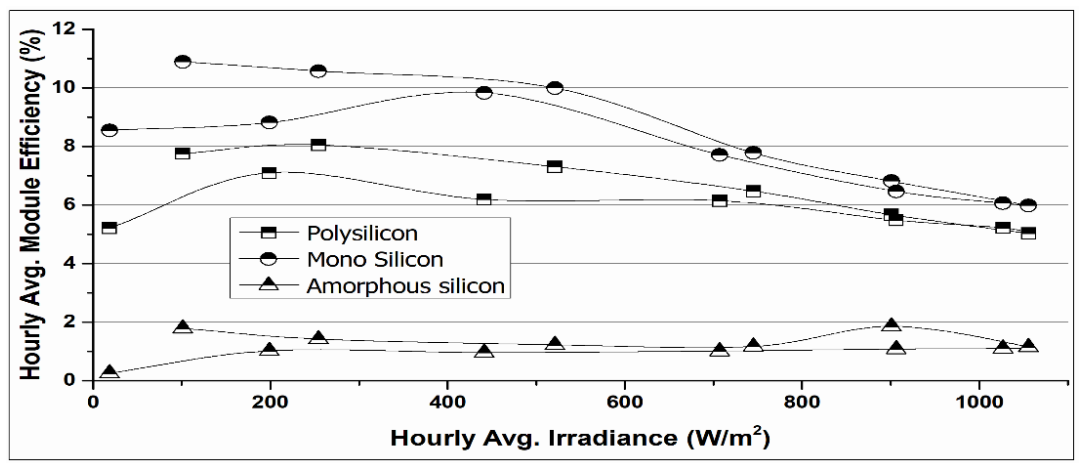

Fig. 10. Avg. Module Efficiency Against Avg. Incident Solar Irradiance.

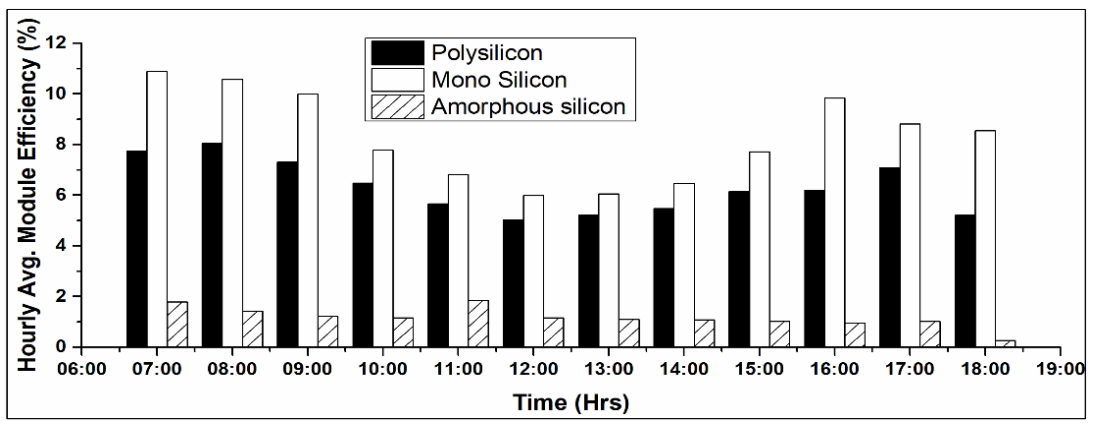

Fig. 11. Hourly Avg. Module Efficiency Values Against Time Hours During Experimentation Days.

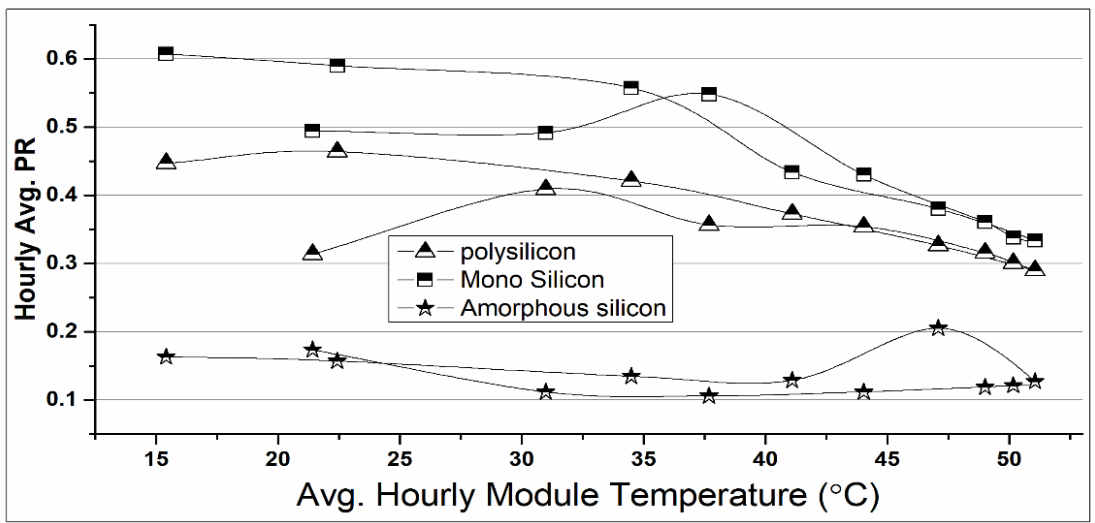

Fig. 12. Hourly Avg. PR Against Hourly Avg. Module Temperature Values.

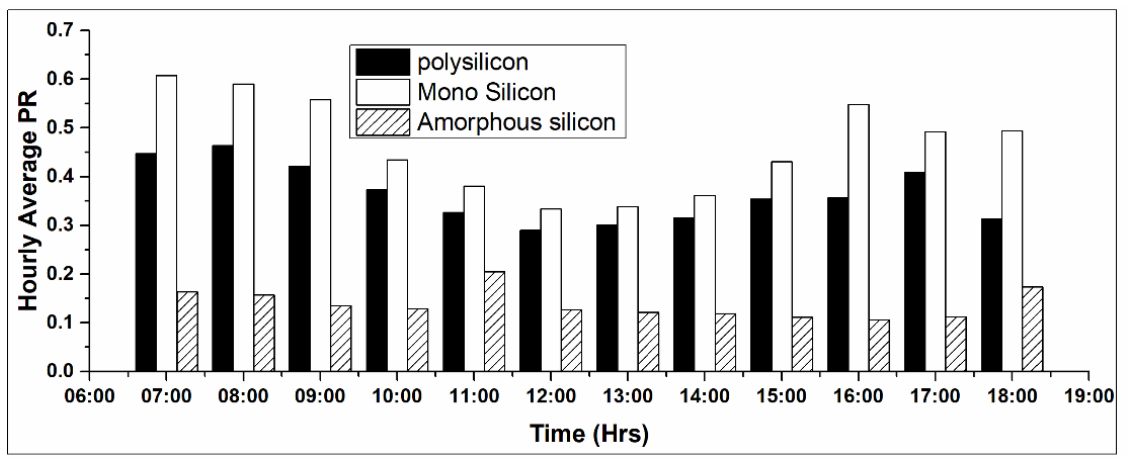

Fig. 13. Hourly Avg. PR Values for Time Hours During Experimentation Days. 


\section{ECONOMIC IMPACT OF POWER SOURCE REPLACEMENT}

Economy is the major concern in making any technology or project viable. The current study elaborates the performance of three types of PV technologies to recommend the optimum choice for installing in domestic sector with the purpose of satisfying domestic load demand. Economic analysis of the experimentally tested systems is done in terms of the price of the consumed power from grid in base case. Analysis reveals that the installation of $1 \mathrm{~kW}$ PV system using m-Si technology will generate $2.53 \mathrm{kWh}$ avg. normalized power per day which is $22.2 \%$ more than the power value that could be produced through p-Si PV technology-based system (equivalent to 2.07 $\mathrm{kWh}$ avg. normalized power per day value). While $1 \mathrm{~kW} \mathrm{PV}$ system installed using a-Si technology will generate $1.09 \mathrm{kWh}$ avg. normalized power per day. In domestic sector of the country region with $3^{\text {rd }}$ largest population [26] count (Faisalabad, Pakistan), where average power consumption per house is around 100-200 kWh per month [27]: installation of such $1 \mathrm{~kW}$ m-Si technology based PV system would result in $38-76 \%$ reduction in electricity bills, while p-Si technology based $1 \mathrm{~kW}$ PV system would result in 31-62\% reduction and a-Si technology based $1 \mathrm{~kW}$ PV system would lead to $16-33 \%$ reduced monthly electricity bills.

\section{CONCLUSION}

A standalone PV system setup was installed at the rooftop of Faisalabad, Pakistan. Three different types of PV technologies (m-Si, p-Si, a-Si) were tested to identify the impact of these renewable technologies on domestic power demand satisfaction. Within the scope of this work, the hourly output power, NPOE, module efficiency, and PR of three modules were measured, and variations in these parameters with variant solar irradiance and surface temperature of PV modules conditions were investigated. Outcomes have elaborated that the output power, and corresponding module efficiency and PR factors, increases with the increase in incident solar irradiance value and surface area of the module, but upto certain limit value. After that limit value, efficiency values start decreasing because module temperature has crossed its nominal operating temperature value.

With the aim of addressing the curiosity that how much impact a certain type of PV technology will impose on domestic sector load demand at testing location, a comparative analysis of three types of PV module has been carried out. Analysis concluded that $\mathrm{m}-\mathrm{Si} \mathrm{PV}$ technology is the optimum choice with $23.01 \%$ avg. NPOE, $8.29 \%$ avg. module efficiency, $46.68 \%$ PR values, and $2.53 \mathrm{kWh}$ normalized power per day value which is $22.2 \%$ more than the power generated value compared to $\mathrm{p}-\mathrm{Si}$ type. While $\mathrm{p}-\mathrm{Si} \mathrm{PV}$ technology performs with $19.08 \%$ avg. NPOE, $6.3 \%$ avg. module efficiency, $36.43 \%$ PR values, and $2.07 \mathrm{kWh}$ normalized generated power per day. a-Si PV technology, although showed almost uniform behavior against variant incident solar irradiance values, but is the least efficient type with $7.03 \%$ avg. NPOE, $1.16 \%$ avg. module efficiency, $13.82 \%$ PR values, and $1.09 \mathrm{kWh}$ normalized generated power per day.

Economic evaluation of PV technologies elaborates that m$\mathrm{Si}$ technology will result in maximum possible reduction in electricity bills equivalent to $38-76 \%$. Integration of renewable energy in domestic sector and installation of such systems would put an impressive environmental and economic impact towards power sector sustainability and reducing shortfall.

\section{REFERENCES}

[1] Muhammad Arshad Shehzad Hassan, Minyou Chen, Houfei Lin, Mohammed Hassan Ahmed, Muhammad Zeeshan Khan, Gohar Rehman Chughtai, "Optimization Modeling for Dynamic Price Based Demand Response in Microgrids," Journal of Cleaner Production, vol. 222, pp. 231-241, 2019.

[2] Muhammad Arshad Shehzad Hassan, Minyou Chen, Qiang Li, M. Ali Mehmood, Tingli Cheng, Bo Li, "Microgrid Control and Protection State of the Art: A Comprehensive Overview," Journal of Electrical Systems, Vol. 14, Issue 2, PP. 148-164, 2018.

[3] Ghafoor, A., et al., Current Satus and Overview of Renewable Energy Potential in Pakistan for Continuous Energy Sustainability. Renewable and Sustainable Energy Reviews, 60 (2016), pp. 1332-1342.

[4] Mehmood, A., F.A. Shaikh, and A. Waqas. Modeling of the Solar Photovoltaic Systems to Fulfill the Energy Demand of the Domestic Sector of Pakistan using RETSCREEN Software. Proceedings (IEEE), in Green Energy for Sustainable Development (ICUE), 2014 International Conference and Utility Exhibition on, 2014.

[5] Harijan, K., M.A. Uqaili, and U.K. Mirza, Assessment of Solar PV Power Generation Potential in Pakistan. Journal of Clean Energy Technologies, 3 (2015), 1, pp. 54-56.

[6] Tahri, F., A. Tahri, and T. Oozeki, Performance Evaluation of GridConnected Photovoltaic Systems Based on Two Photovoltaic Module Technologies Under Tropical Climate Conditions. Energy Conversion and Management, 165 (2018), pp. 244-252.

[7] Huld, T., et al., Mapping the Performance of PV Modules, Effects of Module Type and Data Averaging. Solar Energy, 84 (2010), 2, pp. 324338.

[8] Kawagoe, K., Y. Hishikawa, and N. Yamada, Outdoor Direct STC Performance Measurement of PV Modules Based on a Sun-Shading Technique. IEEE Journal of Photovoltaics, 7 (2017), 6, pp. 1725-1730.

[9] Ramli, M.S., S.S.A. Wahid, and K.K. Hassan. A Comparison of Renewable Energy Technologies Using Two Simulation Softwares: HOMER and RETScreen. Proccedings, AIP Conference, 2017, AIP Publishing.

[10] Kroposki, B., et al. A Comparison of Photovoltaic Module Performance Evaluation Methodologies for Energy Ratings. Proceedings (IEEE), in Photovoltaic Energy Conversion, Conference Record of the Twenty Fourth. IEEE Photovoltaic Specialists Conference-1994, 1994 IEEE First World Conference on.

[11] Amin, N., C.W. Lung, and K. Sopian, A Practical Field Study of Various Solar Cells on Their Performance in Malaysia. Renewable Energy, 34 (2009), 8, pp. 1939-1946.

[12] Midtgard, O.-M., et al., A Qualitative Examination of Performance and Energy Yield of Photovoltaic Modules in Southern Norway. Renewable Energy, 35 (2010), 6, pp. 1266-1274.

[13] Rahman, M., M. Hasanuzzaman, and N. Rahim, Effects of Various Parameters on PV-Module Power and Efficiency. Energy Conversion and Management, 103 (2015), pp. 348-358.

[14] Singh, J.P., et al., Comparison of Glass/Glass and Glass/Backsheet PV Modules using Bifacial Silicon Solar Cells. IEEE Journal of Photovoltaics, 5 (2015), 3, pp. 783-791.

[15] Catelani, M., et al. Characterization of Photovoltaic Panels: The effects of Dust. Proceedings (IEEE), International Energy Conference and Exhibition (ENERGYCON), 2012.

[16] Mekhilef, S., R. Saidur, and M. Kamalisarvestani, Effect of Dust, Humidity and Air Velocity on Efficiency of Photovoltaic Cells. Renewable and Sustainable Energy Reviews, 16 (2012), 5, pp. 29202925.

[17] Ferrada, P., et al., Performance Analysis of Photovoltaic Systems of Two Different Technologies in a Coastal Desert Climate Zone of Chile. Solar Energy, 114 (2015), pp. 356-363. 
[18] Skoplaki, E. and J.A. Palyvos, On the Temperature Dependence of Photovoltaic Module Electrical Performance: A Review of Efficiency/Power Correlations. Solar energy, 83 (2009), 5, pp. 614-624.

[19] Li, X., et al., Outdoor Performance and Stability Under Elevated Temperatures and Long - Term Light Soaking of Triple - Layer Mesoporous Perovskite Photovoltaics. Energy Technology, 3 (2015), 6, pp. 551-555.

[20] Tomar, V., et al., Thermal Modeling and Experimental Evaluation of Five Different Photovoltaic Modules Integrated on Prototype Test Cells with and without Water Flow. Energy Conversion and Management, 165 (2018), pp. 219-235.

[21] Jiang, H., L. Lu, and K. Sun, Experimental Investigation of the Impact of Airborne Dust Deposition on the Performance of Solar Photovoltaic (PV) Modules. Atmospheric Environment, 45 (2011), 25, pp. 42994304.
[22] Bashir, M.A., et al., An Experimental Investigation of Performance of Photovoltaic Modules in Pakistan. Thermal Science, 19 (2015), Supplement 2, pp. 525-534.

[23] Green, M.A., et al., Solar Cell Efficiency Tables (Version 45). Progress in Photovoltaics: Research and Applications, 23 (2015), 1, pp. 1-9.

[24] Cañete, C., J. Carretero, and M. Sidrach-de-Cardona, Energy Performance of Different Photovoltaic Module Technologies under Outdoor Conditions. Energy, 65 (2014), pp. 295-302.

[25] Said, Z. and A. Mehmood, Standalone Photovoltaic System Assessment for Major Cities of United Arab Emirates Based on Simulated Results. Journal of Cleaner Production, 142 (2017), pp. 2722-2729.

[26] PBS, Populaiton, Pakistan Bureau of Statics, Government of Pakistan. 2018.

[27] FESCO, Domestic electricty billing, Faisalabad Electric Supply Company (FESCO), WAPDA, Government of Pakistan. 2018. 